\title{
PENERAPAN TEKNOLOGI INFORMASI DAN KOMUNIKASI PADA AGRIBISNIS SAYURAN ORGANIK
}

\author{
Anne Charina, Rani Andriani, Agriani Hermita, dan Yosini Deliana \\ Program Studi Agribisnis Fakultas Pertanian Universitas Padjadjaran \\ Email : anne.sosek@gmail.com
}

\begin{abstract}
ABSTRAK
Pasar bebas MEA merupakan peluang yang perlu ditangkap oleh berbagai pelaku usaha agribisnis. Termasuk aribisnis sayuran organic yang saat ini sedang berkembang pesat dengan demand yang cukup besar. Untuk itu Teknologi Informasi dan Komunikasi (TIK) menjadi salahsatu komponen yang harus dipersiapkan untuk mendukung pasar bebas MEA. Tulisan ini bertujuan untuk membahas penerapan TIK dalam agribisnis sayuran organic, kendala yang dihadapi beserta strategi perbaikan untuk meningkatkan daya saing dalam menghadapi perdagangan bebas. Penelitian ini dilakukan di Kelompok Tani Semai Organik yang mengusahakan agribisnis sayuran organic, berlokasi di Desa Pada Asih Kecamatan Parompong Kabupaten Bandung Barat. Dengan informan pengurus dan anggota poktan sebanyak 10 orang. Desa Pada Asih sendiri saat ini terpilih menjadi salah satu Desa Organik di Jawa Barat. Metode penelitian yang digunakan adalah studi kasus dengan menggunakan teknik analisis kualitatif. Analisis strategi perbaikan dalam penerapan TIK menggunakan system thinking dengan alat analisis Causal Loop Diagram. Berdasarkan hasil penelitian, terdapat beberapa kendala dalam penerapan TIK di Kelompok Tani Semai Organik, diantaranya dibagi atas kendala budaya, fasilitas dan keterampilan. Strategi perbaikan penerapan TIK yang tepat bagi Kelompok Tani Semai Organik dalam menghadapi pasar bebas MEA diantaranya adalah: Integrasi pemanfaatan TIK dengan program Desa Organic, pemberian subsidi sarana prasarana TIK dari program Desa Organik; sosialisasi penyuluhan berbasis internet (cyberextension); serta focus utama pada peningkatan kompetensi pengurus dalam memanfaatkan TIK. Diharapkan dengan pemanfaatan TIK yang lebih baik, Poktan Semai Organik dapat eksis langsung ke pasar MEA.
\end{abstract}

Kata kunci : Teknologi Informasi dan Komunikasi, kendala, sayuran organic

\begin{abstract}
MEA free market is an opportunity that needs to be captured by various agribusiness actors. Including organic vegetable aribisnis that is currently growing rapidly with considerable demand. For that Information and Communication Technology (ICT) to be one component that must be prepared to support the free market MEA. This paper discusses the application of ICT in organic vegetable agribusiness to improve competitiveness in the face of free trade. This research was conducted at Semai Organic Farmer Group which cultivated organic vegetable agribusiness, located in Pada AsihVillage, Parompong District, West Bandung Regency. 10 informan used are staff and members of poktan. Pada Asih itself is currently selected to be Organic Village in West Java. The research method used is case study and using qualitative analysis technique. Analysis of improvement strategies in the application of ICT using system thinking with Causal Loop Diagram analysis tool. Based on the results of the research, there are several obstacles in the application of ICT in Semai Organic Farmer Group, including divided on cultural constraints, facilities and skills. Strategies to improve the proper application of ICT for Organic Farmers Group in facing MEA free market are: Integration of ICT socialization with Organic Village program, subsidizing ICT infrastructure facilities from Organic Village program; Socialization of internet based education (cyberextension); and focus to grow up staf competency. Expected with better ICT utilization, Semai OrganicFarmer Group can exist directly to the MEA market.
\end{abstract}

Keywords : Information and Communication Technology, constraint, organic vegetable 


\section{PENDAHULUAN}

Era perdagangan bebas yang saat ini mulai dirasakan oleh berbagai kalangan bisnis di seluruh penjuru dunia, termasuk para pelaku agribisnis di negara kita, yaitu petani. Pada kondisi ini petani dihadapkan pada terjadinya aliran bebas barang, jasa, investasi, modal, dan tenaga kerja terampil secara global.

Peningkatan daya saing petani di pasar global harus menjadi prioritas utama sektor pertanian apabila tidak ingin pasar Indonesia sebagai negara agraris didominasi oleh komoditas impor (Badan Litbang pertanian, 2010). Untuk memenuhi tuntutan yang semakin besar terhadap sektor pertanian khususnya hortikultura, maka diperlukan adanya upaya pengembangan di berbagai sisi, termasuk pengembangan sistem teknologi informasi dan komunikasi. Penguasaan Teknologi Informasi dan Komunikasi (TIK) oleh berbagai pihak di bidang pertanian menjadi keharusan.

Secara umum teknologi informasi dan komunikasi dapat diartikan sebagai semua teknologi yang berhubungan dengan pengambilan, pengumpulan, pengolahan, penyimpanan, penyebaran, dan penyajian informasi (Gelb E, 2014). TIK mencakup dua aspek perpaduan yang tidak terpisahkan yaitu teknologi informasi dan teknologi komunikasi. Teknologi informasi meliputi segala hal yang berkaitan dengan proses, penggunaan sebagai alat bantu, manipulasi, dan pengelolaan informasi. Sedangkan teknologi komunikasi berkaitan dengan penggunaan alat bantu untuk memproses dan mentransfer data dari perangkat satu ke perangkat yang lainnya. TIK sangatlah dibutuhkan oleh poktan dalam menjalankan usahanya.

Kelompok Tani Semai Organik merupakan kelompok yang mengusahakan sayuran organic seperti buncis wortel, kangkung, bayam, selada dan lai lain. Poktan ini telah mendapatkan sertifikat organic dari INOVIS. Permintaan akan sayur organic saat ini melonjak sebesar 25\% tiap tahunnya, sayangnya permintaan ini belum bisa terpenui oleh poktan Semai Organik.

Poktan Semai Organik berlokasi di Desa Pada Asih, yang merupakan salah satu desa organic hortikultura di Jawa Barat. Dengan predikat sebagai Desa Organik, Pada Asih berhak mendapatkan subsidi bantuan fasilitas sarana/prasarana untuk mengembangkan desa organic sebesar Rp.250 juta dari pemerintah.

Hanya sayangnya bantuan ini belum turun sehingga belum bisa dimanfaatkan oleh Poktan Semai Organik selaku potan penerima manfaat dari program Desa Organik.

Sebenarnya Poktan Semai Organik berpotensi besar untuk dapat terjun langsung ke pasar bebas, hanya sayangnya kemudahan dalam mengakses TIK belum sepenuhnya bisa dimanfaatkan oleh anggota Kelompok Tani Semai Organik. Penggunaan TIK di Kelompok Tani Semai Organik hanya sebatas penyebaran informasi dan komunikasi di lingkungan eksternal sedangkan penggunaan TIK di internal poktan sendiri sangat minim.

Relevansi informasi pertanian yang tersedia baik di radio, televisi, tabloid, dan leaflet tidak spesifik yang dibutuhkan petani dalam usahataninya, sehingga belum mampu menimbulkan rasa butuh pada petani akan penggunaan TIK. Sejauh ini petani merasa belum penting untuk menggunakan TIK dalam aktifitas usaha tanimya.

Kondisi ini menjadi tantangan dalam pengembangan kapasitas dan kapabilitas poktan untuk memperoleh informasi dalam menghadapi pasar bebas. Untuk menghadapi tantangan dan peluang yang ada, Kelompok Tani Semai Organik perlu menetapkan strategi penggunaan TIK yang tepat bagi mereka agar mampu bersaing dalam menghadapi pasar bebas. Penelitian ini bertujuan untuk: Mengetahui kendala yang dihadapi Kelompok Tani Semai Organik dalam penggunaan TIK. Serta merancang strategi yang tepat bagi poktan untuk mengembangkan kapasitas dan kapabilitas dalam penggunaan TIK.

\section{METODE PENELITIAN}

Objek penelitian ini adalah kendala dalam penerapan TIK dan strategi yang tepat dalam penerapan dan pengembangan teknologi informasi dan komunikasi di Kelompok Tani Semai Organik.

Penelitian dilakukan di Kelompok Tani Semai Organik, DesaPada Asih, Kecamatan Parompong Kabupaten Bandung Barat, Jawa Barat. Pemilihan tempat penelitian tersebut didasarkan atas pertimbangan bahwa Kelompok Tani Semai Organik merupakan poktan yang sudah mulai menerapakan teknologi informasi dan komunikasi dan merupakan kelompok tani organic satu satunya di Kecamatan Parompong yang telah tersertifikasi INOVIS, sehingga peluangnya untuk masuk ke pasar MEA terbuka lebar. 
Desain penelitian ini adalah kualitatif.

Teknik penelitian yang digunakan adalah studi kasus (case study). Jenis sumber data yang digunakan pada penelitian ini adalah data primer dan data sekunder. Sumber data primer diperoleh dari hasil observasi/pengamatan dan wawancara dengan informan yaitu petani pengurus dan anggota di Kelompok Tani Semai Organik. Teknik pengumpulan data yang dilakukan dalan penelitian ini adalah observasi, wawancara, dan studi literatur.

Analisis deskriptif digunakan untuk menganalisis penerapan TIK serta mengetahui kendala penerapan TIK yang dihadapi Poktan Semai organik. System thinking dengan alata analisis causal loop diagram digunakan untuk melihat masalah-masalah penerapan TIK yang memiliki dampak dalam menghadapi pasar bebas, sehingga bermanfaat dalam menentukan strategi pengembangan TIK yang tepat untuk di Kelompok Tani Semai Organik (Kim, 1999).

\section{HASIL DAN PEMBAHASAN}

Kendala Penerapan Teknologi Informasi dan Komunikasi di Kelompok Tani Semai Organik. Teknologi Informasi dan Komunikasi di Kelompok Tani Semai Organik sudah mulai diterapkan, hanya terbatas pada lingkungan kecil saja. Seperti penggunaan HP untuk transaksi serta pencatatan transaksi dalam computer. Untuk TIK lainnya belum banyak yang digunakan. Hal ini disinyalir karena beberapa kendala dibawah ini:

\section{Kendala Fasilitas (Facility}

Constraint). Upaya Kelompok Tani Semai Organik dalam memanfaatkan TIK ternyata tidak didukung infrastruktur penunjang yang memadai. Poktan belum memiliki jaringan kabel untuk internet, serta belum memiliki jaringan telepon. Sebenarnya Desa Padaasih yang berhasil mendapatkan dana sebagai Desa Organik tahun 2016 memiliki peluang besar untuk memperoleh fasilitas TIK dari program desa organic. Hal tersebut sejalan hasil penelitian Douft, 2013 yang mengemukakan bahwa website merupakan teknologi komunikasi dan informasi yang sangat penting bagi unit usaha dan memiliki efek paling besar dalam menjaring konsumen luar di era internet saat ini. Dalam membuat dan mengelola website tentunya bukan hal yang mudah, poktan membutuhkan tenaga IT yang bisa disewa untuk pengelolaan website nantinya. Sampai saat ini poktan baru memiliki perangkat computer 2 buah. Jaringan telepon dan faximile pun belum tersedia, sehingga komunikasi digunakan dengan dengan telepon seluler. Dari perhitungan di lapangan didapatkan data bahwa $65 \%$ petani merasa kendala yang paling dominan dalam menggunakan TIK karena keterbatasan fasilitas/sarana prasarana yang dimiliki.

Kendala Keterampilan (Skill Constraint). Dalam penerapannya, penggunaan TIK di Kelompok Tani Semai Organik masih terbentur kendala keterampilan. Sekitar 53\% dari responden mengemukakan belummaksimalnya penggunaan TIK karena factor keterampilan petani yang rendah. Keterampilan yang rendah ini dikarenakan rendahnya pengetahuan tentang TIK . Sarana prasarana tidak mendukung serta belum adanya sosialisasi pentingnya TIK serta Pelatihan penggunaan TIK, membuat petani jauh dari kebiasaan menggunakan piranti teknologi baik informasi maupun komunikasi. Namun yang paling utama TIK sebenarnya wajib dipahami oleh para pengurus poktan terlebih dahulu. Untuk petani yang ada di lapangan, TIK tidak sepenting bagi pengurus poktan.

Hal ini tentunya tidak bisa kita salahkan sepenuhnya, peggunaan TIK idealnya memang dipahami oleh semua anggota, tetapi sebagimana yang dikemukakan diatas yang diutamakan level pengurus poktan terlebih dahulu memahami dan memiliki keterampilan dalam penggunaan TIK, karena penguruslah yang nantinya terlibat langsung dalam penggunaan TIK untuk agribisnis sayuran organic. Ini sejalan juga dengan hasil penelitian Subedjo, 2015 yang mengemukakan bahwa TIK penting digunakan pada petanidengan posisi pengurus poktan atau poktan.

Dari sisi penyuluh, pemanfaatan TIK justru belum terlaksana. Hal ini terlihat dari penyuluhan pertanian yang belum menerapkan sistem cyber extension. Hal ini terkait dengan keterampilan penyuluh itu sendiri. Diharapkan untuk kedepannya dalam menghadapi tantangan pasar bebas, integrasi dari berbagai sector pendukung yaitu pemerintah dan penyuluh akan mampu bersinergi dengan poktan dalam memanfaatkan TIK sebagai media untuk memperluas jejaring.

Kendala Budaya (Culture 
Constraint). Kendala lain yang juga mempengaruhi penerapan TIK di Kelompok Tani Semai Organik adalah budaya yang melekat pada diri petani itu sendiri (Ambar, 2004). Ketika petani tidak mendapatkan informasi mengenai pentingnya TIK, maka petani tersebut tidak akan merasa butuh TIK. Kurangnya minat baca petani menjadi salah satu penyebab hal ini. Penyebab lain kurangnya kemauan petani untuk menggunakan TIK adalah kemampuan penerjemahan petani akan sesuatu yang dibaca masih kurang, baik karena faktor usia, pendidikan, maupun bahasa. Petani lebih tertarik untuk menerima informasi praktek langsung. Mereka lebih memilih untuk fokus dalam pekerjaan dan memenuhi permintaan konsumen.Selain mengalami berbagai kendala dalam penerapan TIK

Petani merasa belum membutuhkan TIK dalam aktifitas usaha taninya. Pemahaman akan pentingnya TIK sebenarnya dapat dilakukan dengan pendekatan kelompok dan pendekatan personal oleh penyuluh dan juga oleh fasilitator Desa Organik. Apalagi jika dilihat hamper $76 \%$ lebih petani sayur organic tingkat usianya masih muda dan produktif sehingga jika diberi pengetahuan dan keterampilan mereka akan cenderung lebih adaptif dan mudah dalam menerima inovasi baru.

Strategi Perbaikan Pemanfaatan TIK di Kelompok Tani Semai Organik. Hasil pengamatan sistem penerapan dan kendala penerapan TIK di Kelompok Tani Semai Organik telah dideskripsikan sebelumnya sehingga dapat ditentukan variabel-variabel yang diperkirakan mempunyai pengaruh secara langsung, sistematis, dan logis. Variabel adalah suatu kondisi, situasi, tindakan, atau keputusan yang mempengaruhi dan dapat dipengaruhi oleh variabel-variabel lain (Basyid, 2006). Berdasarkan fakta yang dapat dikumpulkan di poktan kemudian diolah berdasarkan petunjuk dari Sherdood, dapat ditemukenali beberapa variable yang memiliki pengaruh dalan penerapan TIK di Poktan Semai Organik, yaitu:

1. Penerapan TIK di Semai Organik

2. Biaya Penggunaan TIK

3. Infrastruktur Jaringan

4. Sarana Prasarana Pendukung

5. Peran Penyuluh dalam Memanfaatkan TIK

6. Sosialisasi Manfaat TIK

7. Pelatihan Penggunaan TIK
8. Keterampilan Petani Menggunakan TIK

9. Pengetahuan Petani akan Manfaat TIK

10. Motivasi petani dalam memanfaatkan TIK

11. Program Desa Organik

12. Peran Fasilitator Desa Organik

13. Dukungan Stakeholder terkait

14. Fasilitas Desa Organik

15. Keterampilan Pengurus dalam

Menggunakan TIK

Berdasarkan permasalahan sistem, selanjutnya disusun model sistem yang dimulai dengan menyusun causal loop diagram (CLD) dengan menggunakan program piranti lunak Vensim. Vensim adalah suatu piranti permodelan yang memperkenakan anda untuk mengkosnseptualisasikan, mendokumentasikan, menyimulasikan, menganalisis, dan mengoptimalkan model dalam sistem dinamis (Mulyandari, 2005).

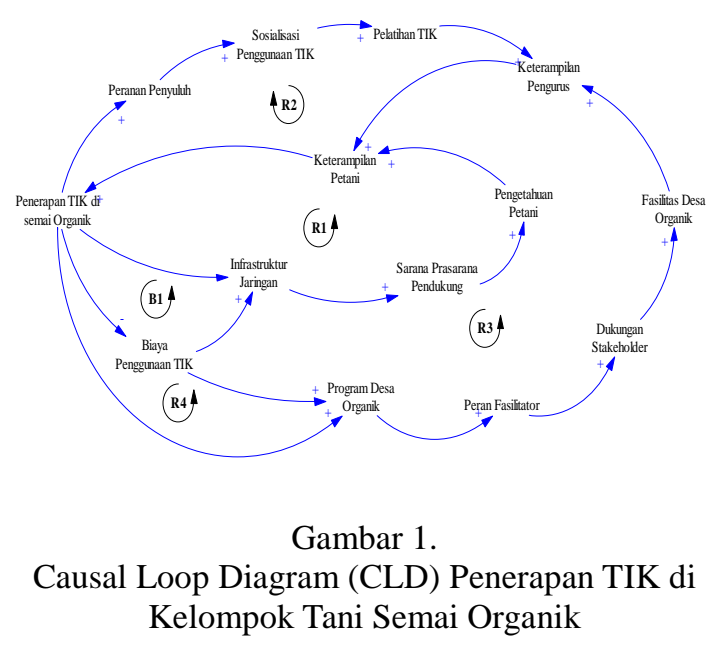

Mengidentifikasi Variabel Pengungkit

(Leverage). Setelah menyelesaikan penyusunan CLD masalah penerapan TIK di Kelompok Tani Semai Organik, langkah selanjutnya ialah menentukan variabel pengungkit, atau kadang-kadang dinamakan variabel utama. Untuk tujuan ini, perlu identifikasi setiap variabel dalam CLD, mencari jumlah lup yang melalui setiap variabel, selanjutnya menentukan peringkatnya. Variabel yang terbanyak dilalui oleh lup dinamakan variabel pengungkit.

Analisis CLD. Berdasarkan CLD pada yang telah disusun, terdapat tiga lingkaran (loop) yang menunjukkan hubungan yang berbanding lurus atau disebut juga dengan Reinforcing Feedback (R).

R1 menunjukkan penerapan TIK di Semai Organik akan sangat dipengaruhi oleh 
infrastruktur serta sarana prasarana yang menunjang. Jika sarana prasarana serta infrastruktur seperti jaringan telepon, jaringan internet, website dll dimiliki oleh poktan maka pengetahuan dan keterampilan petani akan TIK akan bertambah. Pengetahuan petani akan manfaat TIK akan mempengaruhi kemauan petani melakukan dokumentasi, berbagi informasi, dan meluangkan waktunya menggunakan sarana TIK. Apabila petani sudah terbiasa dengan penggunaan TIK, kemampuan petani dalam menggunakannya juga akan semakin meningkat sehingga pengembangan penerapan TIK di poktan dapat terlaksana dengan baik

Tabel 1.

Variabel yang Dilalui oleh Lup

\begin{tabular}{|c|c|c|c|}
\hline No & Variabel & $\begin{array}{l}\text { Lup } \\
\text { yang } \\
\text { melalui }\end{array}$ & $\begin{array}{l}\text { Pering- } \\
\text { kat }\end{array}$ \\
\hline 1 & $\begin{array}{l}\text { Kebijakan Penerapan TIK } \\
\text { di Semai Organik }\end{array}$ & 5 & I \\
\hline 2 & Biaya Penggunaan TIK & 2 & III \\
\hline 3 & Infrastruktur Jaringan & 2 & III \\
\hline 4 & $\begin{array}{l}\text { Sarana Prasarana } \\
\text { Pendukung }\end{array}$ & 2 & III \\
\hline 5 & $\begin{array}{l}\text { Peran Penyuluh dalam } \\
\text { Memanfaatkan TIK }\end{array}$ & 1 & IV \\
\hline 6 & Sosialisasi Manfaat TIK & 1 & IV \\
\hline 7 & Pelatihan Penggunaan TIK & 1 & IV \\
\hline 8 & $\begin{array}{l}\text { Keterampilan Petani } \\
\text { Menggunakan TIK }\end{array}$ & 2 & III \\
\hline 9 & $\begin{array}{l}\text { Pengetahuan Petani akan } \\
\text { Manfaat TIK }\end{array}$ & 2 & III \\
\hline 10 & $\begin{array}{l}\text { Motivasi petani dalam } \\
\text { memanfaatkan TIK }\end{array}$ & 1 & IV \\
\hline 11 & Program Desa Organik & 4 & II \\
\hline 12 & $\begin{array}{l}\text { Peran Fasilitator Desa } \\
\text { Organik }\end{array}$ & 2 & III \\
\hline 13 & $\begin{array}{l}\text { Dukungan Stakeholder } \\
\text { terkait }\end{array}$ & 2 & III \\
\hline 14 & Fasilitas Desa Organik & 2 & III \\
\hline 15 & $\begin{array}{l}\text { Keterampilan Pengurus } \\
\text { dalam Memanfaatkan } \\
\text { TIK }\end{array}$ & 4 & II \\
\hline
\end{tabular}

R2 menunjukan bahwa penerapan TIK akan dipengaruhi oleh kemampuan penyuluh. Jika penyuluh intens memberikan sosialisasi akan manfaat TIK bagi pengurus poktan serta memberikan penyuluhan terkait pemanfaatan TIK pada pengurus, maka otomatis keterampilan pengurus sebagai pelaksana inti yang akan mengoperasionalkan TIK akan meningkat. Dari causa loop terlihat bahwa pengurus poktan merupakan variable utama yang perlu diperhatikan yang akan menentukan keberhasilan penerapan TIK di Poktan Semai Organik.

Lup R3 menunjukkan bahwa penerapan TIK sangat dipengaruhi oleh fasilitator desa organic. Dengan koordinasi bersama semua stakeholder yang terkait serta ditunjang fasilitas yang mendukung akan membantu pengurus poktan dalam mempelajari dan memahami TIK. Jika pengurus poktan telah memahami teknik dalam penggunaan TIK nantinya akan dishare kepada semua anggota poktan, sehingga keterampilan anggota poktan pun akan TIK meningkat.

Lup R4 menunjukan bahwa penerapan TIK di Semai Organik sangat dipengaruhi oleh berjalannya program desa organic Pada Asih. Poktan Semai Organik selaku poktan penerima manfaat dari Desa Organik Pada Asih, dapat memanfaatkan fasilitas yang diberikan melalui Program Desa Organik. Poktan bisa mengajukan kebutuhan untuk TIK baik sarana prasarana maupun bentuk-bentuk pelatihan yang menunjang agar pengurus bisa memahami dan menguasai penerapan TIK untuk memperluas pasar dan jejaring masuk ke pasar bebas MEA.

Terdapat satu lingkaran dengan tanda yang berbeda atau disebut Balancing Feedback (B) yang menunjukkan hubungan negatif. Lup B1 menunjukkan pengembangan penerapan TIK di Kelompok Tani Semai Organik dipengaruhi secara langsung oleh biaya. Biaya dalam pemanfaatan TIK tentunya mahal.. Kebijakan subsudi bagi poktan yaitu yang berasal dari Desa Organik dalam penarapan TIK akan membantu petani menurunkan biaya penggunaan TIK. Penurunan biaya penggunaan TIK akan memicu meningkatnya penggunaan hardware dan software TIK di lingkungan Kelompok Tani Semai Organik, sekaligus meningkatkan pengembangan penerapan TIK di Kelompok Tani Semai Organik.

Setelah menyusun CLD dan mengolahnya menggunakan piranti lunak vensim, diperoleh data bahwa variabel yang paling banyak dilalui oleh lup adalah variabel kebijakan penerapakan TIK yang disebut sebagai variabel pengungkit (leverage). Artinya Strategi perbaikan yang bisa kita lakukan dalam penerapan TIKdi Semai Organik dengan memperhatikan variable 
tersebut. Perbaikan kualitas dan kuantitas kebijakan penerapan TIK di Kelompok Tani Semai Organik harus menjadi prioritas utama sebagai langkah awal pemberdayaan bagi poktan untuk mengembangkan kapasitas dan kapabilitas penggunaan TIK.

Kebijakan penerapan TIK juga akan meningkat apabila program desa organic berjalan. Semakin cepat program desa organic pada asih berjalan maka akan semakin cepat poktan semai dalam menerima manfaat yang akan digunakan untuk memenuhi kebutuhan sarana pendukung TIK baik berupa berangkat hard ware ataupun software. Dengan berjalannya program desa organic, poktan akan memiliki kesempatan untuk mendapatkan berbagai pelatihan TIK sesuai dengan kebutuhan.

Pengembangan penerapan TIK akan dipengaruhi oleh kompetensi pengurus poktan. Karena sejatinya orang yang paling tepat untuk mngelola TIK di poktan adalah sampai level pengurus terlebih dahulu, kemudian bertahap sampai anggota tani siap. Pengembangan penerapan TIK di Kelompok Tani Semai Organik dipengaruhi oleh biaya penggunaan TIK, infrastruktur jaringan dan kemampuan petani dalam menggunakan TIK. Semakin kecil biaya yang harus dikeluarkan poktan akan meningkatkan kemauan poktan dalam menerapkan dan mengembangkan penerapan TIK.

Penggunaan penerapan TIK membutuhkan dana yang tidak sedikit. Sementara Kelompok Tani Semai Organik serta masyarakat desa belum mempunyai kemampuan finansial yang cukup baik untuk mendukungnya. Diharapkan dengan bantuan Rp.250jt untuk pengembangan Desa organic bisa dijadikan subsidi untuk memenuhi kebutuhan TIK di poktan Semai Organik.

\section{KESIMPULAN}

1. Terdapat beberapa kendala dalam penerapan TIK di Kelompok Tani Semai Organik. Kendala tersebut dibagi atas kendala fasilitas, keterampilan serta budaya. Hasil analisis menunjukkan bahwa kendala paling dominan menurut para petani dalam penerapan TIK karena karena keterbatasan fasilitas/sarana prasarana TIK yang belum dimiliki.

2. Strategi perbaikan yang paling tepat dalam menerapkan TIK di Poktan Semai Organik adalah Integrasi pemanfaatan TIK dengan program Desa Organic, pemberian subsidi sarana prasarana TIK dari program Desa Organik; sosialisasi penyuluhan berbasis internet (cyberextension); serta focus utama pada peningkatan kompetensi pengurus dalam memanfaatkan TIK.

\section{UCAPAN TERIMAKASIH}

Terima Kasih kepada Rektor Universitas Padjadjaran yang telah mendanai Penelitian ini, yang merupakan bagian dari Penelitian Riset Fundamental Unpad 2017.

\section{DAFTAR PUSTAKA}

Ambar Teguh Sulistyani. 2004. Kemitraan dan Model-model Pemberdayaan. Jakarta: Gava Media.

Badan Litbang Pertanian. 2010. Revitalisasi Radio Pertanian Melalui http://www.litbang.pertanian.go.id/warta -ip/pdf-file/5.retno_vol19-1-10.pdf. 6 Juli 2016

Basyid, Abdul. 2006. Pemberdayaan Masyarakat Pertanian Melalui Penguatan Modal Usaha Kelompok Petani. Jakarta: Departemen Pertanian.

Gelb E., Wagner P., Rosskopf K., Parker C. \& Schiefer G., 2004. ICT adoption -A summary of the EFITA questionnaires. Proceedings AFITA/WCCA Congress, Bangkok, Thailand

Kim, Daniel H. 1999. Introduction of System Thinking. Pegasus Com

Mulyandari, RSH. 2005. Alternatif Model Diseminasi Informasi Teknologi Pertanian Mendukung Pengembangan Pertanian Lahan Marginal. dalam buku Informasi Teknologi Dalam Pertanian Lahan Marginal.Susanto,

Mulyandari, R.S.H. dan E.E. Ananto. 2005. Teknik implementasi pengembangan sumber informasi pertanian nasional dan lokal P4MI. Informatika Pertanian, 14: 802-817. 